\title{
Film-Coated Tablet and Gastro-Resistant Granules in Sachet
}

National Cancer Institute

\section{Source}

National Cancer Institute. Film-Coated Tablet and Gastro-Resistant Granules in Sachet. NCI Thesaurus. Code C149516.

Medicinal product consisting of a film-coated tablet and gastro-resistant granules presented together in a sachet and intended to be swallowed together as a single dose. 